
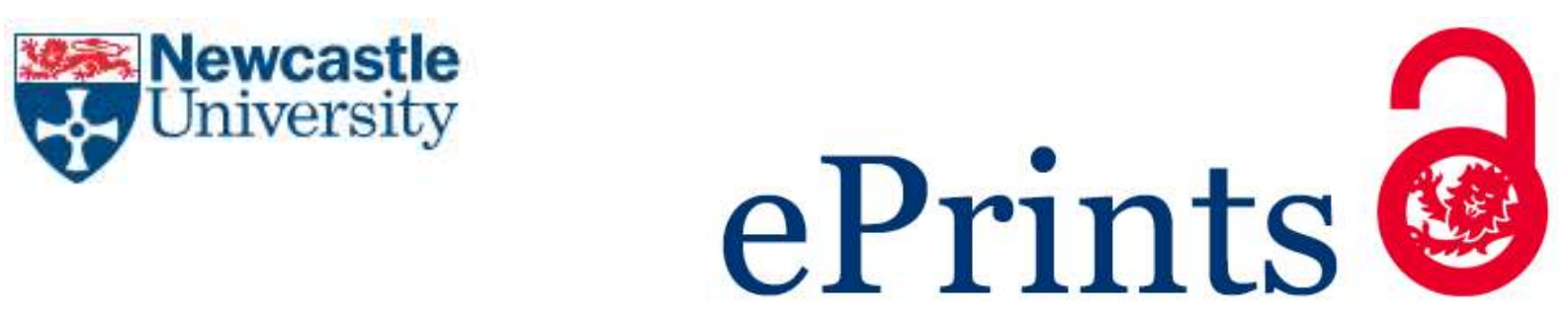

Benwell MC. Reframing Memory in the School Classroom: Remembering the Malvinas War. Journal of Latin American Studies 2015

\title{
Copyright:
}

C2015 Cambridge University Press.

The publisher allows for the accepted manuscript to be made available on an institutional repository after acceptance of publication.

DOI link to article:

http://dx.doi.org/10.1017/S0022216X15001248

Date deposited:

$14 / 12 / 2015$

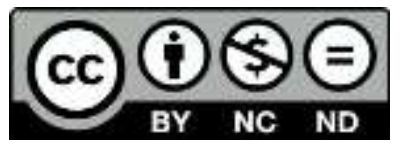

This work is licensed under a

Creative Commons Attribution-NonCommercial-NoDerivatives 4.0 International licence 


\section{Reframing memory in the school classroom: remembering the Malvinas war}

Abstract: Narratives of memory have received considerable attention in Argentina but rarely have these been examined in relation to the 1982 Malvinas War. This paper focuses on national memory narratives of the war manifest in educational resources and explores how and under what conditions local ways of remembering can transform and/or reproduce such narratives, through research within secondary schools in Río Gallegos, a city in the south of Argentina. It shows how the city's connections with the military and the war generated sensitivities that influenced how the Malvinas was engaged in the classroom. The localised framings deviated from predominant national memory narratives by underplaying the broader context of state terror and overlooking histories associated with the Malvinas before 1982.

Key words: Memory, Commemoration, Education, Argentina, Malvinas War.

\section{Introduction}

Memory has long attracted attention across the social sciences and research undertaken in nations comprising the Southern Cone has made insightful and original contributions to these literatures. Much of the regional work on memory has critically examined the ways in which Argentina, Brazil, Chile and Uruguay have variously negotiated remembering their troubled histories, principally those associated with human rights atrocities committed by military dictatorships across the continent in the second half of the twentieth century. In the context of Argentina, the focus of research has been drawn to "how memory is produced and constructed' in relation to state terrorism unleashed by the last military dictatorship 
which was in power from 1976-83. ${ }^{1}$ With the notable exception of work from Guber and Lorenz, much less work has examined the ways in which Argentine society has remembered and commemorated the 1982 Malvinas War. ${ }^{2}$ The war was instigated by and bound up with the final throes of the last military dictatorship in Argentina and these close links, allied with the nature of the transition to democracy, were influential in the episode's relative marginalisation. For instance, in the initial years following the war Argentina was gradually coming to terms with the extent of crimes committed by its military institutions against the civilian population, leaving little room for commemoration of the Malvinas War and its protagonists. In short, the memory narratives associated with the 'disappeared' as innocent victims of the dictatorship contained fewer contradictions than the returning war veterans, for a society trying to establish its pacifist credentials based on democratic values and human rights. ${ }^{3}$ This paper looks to address some of these absences and contradictions by looking directly at how the Malvinas War is being remembered across Argentina over 30 years on, in ways which connect with broader debates about memory in Argentine contexts and beyond.

Existing research on memory has become highly sensitive to spatial and temporal variations inherent to the act of remembering. The contested nature of memory narratives have been emphasised as they take on different meanings across space and time, and are framed and 'used' for different ends by governments and other interest groups. ${ }^{4}$ Jelin and Kaufman are

\footnotetext{
${ }^{1}$ Elizabeth Jelin and Susana G. Kaufman, 'Layers of Memories: Twenty Years After in Argentina', in T. G. Ashplant, Graham Dawson and Michael Roper (eds.), The Politics of War Memory and Commemoration (London: Routledge, 2000), p. 89.

2 Federico Lorenz, Las guerras por Malvinas (Buenos Aires: Edhasa, 2006); Federico Lorenz, Todo lo que necesitás saber sobre Malvinas (Buenos Aires: Paidós, 2014); Rosana Guber, ¿Por qué Malvinas? De la causa nacional a la guerra absurda (Buenos Aires: Fondo de Cultura Económica, 2012).

${ }^{3}$ Lorenz, Las guerras por Malvinas.

${ }^{4}$ Fernando J. Bosco, 'Human Rights Politics and Scaled Performances of Memory: Conflicts among the Madres de Plaza de Mayo in Argentina', Social and Cultural Geography, 5 (2004), pp. 381-402; Stephen Legg,
} 
cognisant of these differences in Argentina, making a distinction between the 'public/political context in which memory/oblivion of the military dictatorship unfolded' and the 'personal narratives, in which traces and marks of that past emerge in the development of the life course and in the everyday experiences of people'.$^{5}$ This paper draws on these ideas to consider how official/national memory narratives about the Malvinas War are received and negotiated in and through everyday commemoration practices. It does so by comparing state narratives of the Malvinas War circulated at the national level through educational resources such as textbooks and posters, with the commemorative discourses and practices of schools. ${ }^{6}$ This comparison enables an analysis of when everyday memory practices within schools subscribe to state-sponsored narratives, and when they depart from and reframe those narratives. As a result, this paper goes further than simply suggesting that official discourses of memory can be locally contested and transformed (or not), by alluding to some of the conditions under which they are likely to be reframed or reproduced.

In order to get a sense of national and local narratives regarding the Malvinas War, the research presented here was conducted in Argentina's capital Buenos Aires and Río Gallegos, the provincial capital of Santa Cruz province. It should be pointed out that the fieldwork was undertaken in $2012-13$, coinciding with the $30^{\text {th }}$ anniversary of the Malvinas

\footnotetext{
'Contesting and Surviving Memory: Space, Nation, and Nostalgia in Les Lieux de Mémoire', Environment and Planning D: Society and Space, 23 (2005), pp. 481-504; Ana Ros, The Post-Dictatorship Generation in Argentina, Chile, and Uruguay: Collective Memory and Cultural Production (Basingstoke: Palgrave-Macmillan, 2012).

${ }^{5}$ Jelin and Kaufman, 'Layers of Memories'.

${ }^{6}$ While the academic analysis of textbooks is fairly commonplace, fewer studies have focused on how state narratives are interpreted within school settings although for some pertinent examples see, Michelle J. Bellino, 'Whose Past, Whose Present? Historical Meaning among the 'Postwar' Generation in Guatemala', in James H. Williams (ed.), (Re)Constructing Memory: School Textbooks and the Imagination of the Nation (Rotterdam: Sense Publishers, 2014), pp. 131-52; Lisa Y. Faden, 'History Teachers Imagining the Nation: World War II Narratives in the United States and Canada', in James H. Williams (ed.), (Re)Constructing Memory: School Textbooks and the Imagination of the Nation (Rotterdam: Sense Publishers, 2014), pp. 191-218.
} 
War when an exceptional number of public commemorations and demonstrations were organised throughout Argentina. My empirical data reflects on the activities and events that were organised within schools in Río Gallegos during this anniversary year. In-depth interviews were conducted with eight history teachers (six female and two male) in three private and four public secondary schools in Río Gallegos. The majority of the teachers had moved to the city from provinces in the north such as Santa Fe and Entre Ríos after the 1982 Malvinas War. Representatives from education ministries at the provincial (Santa Cruz) and national level were also interviewed including the Minister of Education for the Nation, Alberto Sileoni, and officials responsible for coordination of the education and memory programme in Argentina. The educational materials produced by these ministries for use in school classrooms were also analysed. Aside from these formally arranged interviews, the research encompassed participant observation in school and public spaces, reflecting in particular on informal conversations with staff at the secondary schools and, more generally, citizens living in Río Gallegos. ${ }^{7}$

The city of Río Gallegos was chosen for the study specifically because of its geographical and historical interconnections with the Malvinas and to provide a counterpoint to previous research undertaken in the capital Buenos Aires. ${ }^{8}$ These local histories and the city's contemporary links with the armed forces were found to be influential in shaping narratives of memory which were presented in distinctive ways to those circulated at the national level. The findings resonate more broadly with memory studies in Latin American contexts which have shown how ways of remembering are increasingly questioning grand, unified

\footnotetext{
7 Diana Milstein and Héctor Mendes, 'Cuerpo y escuela. Dimensiones de la política', Revista Iberoamericana de Educación, 62 (2013), pp. 143-161.

${ }^{8}$ Matthew C. Benwell and Klaus Dodds, 'Argentine Territorial Nationalism Revisited: The Malvinas/Falklands Dispute and Geographies of Everyday Nationalism', Political Geography, 30 (2011), pp. 441-449.
} 
visions of the past presented by the state, in favour of acknowledging geographical, temporal and other complexities which emphasise different agendas and interpretations of memory. ${ }^{9}$ The school, then, is a key site connected to other places and people in the community where dominant state narratives in relation to memory can be localised, questioned, reworked and/or reinforced. ${ }^{10}$

\section{(Re-)interpreting memory and commemoration}

'Social reality is contradictory, full of tensions and conflicts. Memory is not an exception'. ${ }^{11}$

As Jelin and Kaufman suggest here, memory is often subject to contestation; it can be resisted, negotiated, politicised, marginalised and/or reproduced in a host of different ways and work in Argentine contexts has been central to thinking critically about how these processes unfold. Rothberg theorises memory as multidirectional, placing attention on the negotiation and intersection of different memory narratives. Interrogating 'memory's multidirectionality encourages us to think of the public sphere as a malleable discursive space in which groups do not simply articulate established positions but actually come into being through their dialogical interactions with others' ${ }^{12}$ Thus, ways of thinking about memory and forgetting have become more sensitive to the production, circulation and reception of narratives about the past, which can take place at and between diverse geographical scales. Focusing attention on dominant nationalist discourses alone for instance, is understood to risk marginalising memories and narratives that might exist within

\footnotetext{
${ }^{9}$ For example, see, Vikki Bell, 'Afterword: The Politics of "Memory" in the Long Present of the Southern Cone', in Francesca Lessa and Vincent Druliolle (eds.), The Memory of State Terrorism in the Southern Cone: Argentina, Chile and Uruguay (Basingstoke: Palgrave-Macmillan, 2011), pp. 209-21; Bosco, 'Human Rights Politics'.

10 Bellino, 'Whose Past'.

11 Jelin and Kaufman, 'Layers of Memories', p. 90.

12 Michael Rothberg, Multidirectional Memory: Remembering the Holocaust in the Age of Decolonization (Stanford: Stanford University Press, 2009), p. 5.
} 
the nation. ${ }^{13}$ At the same time, it is critical to move beyond the rudimentary observation that national narratives of memory can be subject to re-interpretation at localised scales. Using the work of Hodgkin and Radstone as inspiration, this paper considers the act of remembering as sociologically constructed, selective and contextual. In this sense memory is 'located in specific contexts, instances and narratives and decisions have always to be taken about what story is to be told. ${ }^{\prime 14}$ It is these decisions relating to narratives of memory that are taken between national and local scales which are the main focus of this paper. These differences provide an opportunity for deeper reflection of how official narratives of memory are negotiated and received. As Hodgkin and Radstone state: 'The very fact that there are divergences, inconsistencies, different versions at different times is in itself revealing both about the culture in which these memories have been built and emerge, and about the workings of memory itself. ${ }^{\prime 15}$

Most of the work on memory in an Argentine context has concentrated on how state terrorism associated with the last military dictatorship has been remembered. This work has been similarly sensitive to the pluralism of memory narratives, with Jelin and Kaufman suggesting that, 'one should not expect an 'integration' or 'gelling' of individual and public memories, or the presence of a single memory. There are contradictions, tensions, silences, conflicts, gaps, disjunctions, as well as 'integration' ${ }^{16}$ The meanings of the past are subject to power struggles, can vary over time (with different political administrations, for instance)

\footnotetext{
13 Linda Tabar, 'Memory, Agency, Counter-Narrative: Testimonies from Jenin Refugee Camp', Critical Arts: South-North Cultural Media Studies, 21 (2007), p. 7.

${ }^{14}$ Katharine Hodgkin and Susannah Radstone, 'Transforming Memory', in Katharine Hodgkin and Susannah Radstone (eds.), Contested Pasts: The Politics of Memory (London: Routledge, 2003), p. 5.

${ }^{15}$ Hodgkin and Radstone, 'Transforming Memory', p. 5.

16 Jelin and Kaufman, 'Layers of Memories', p. 90.
} 
and space and are bound up with wider social and political scenarios. ${ }^{17}$ While the highly symbolic and state-organised 'marking of anniversaries with marches and exhibitions and so on suggests that the nation as a whole is reaching for a narrative by which to locate the past, there remains...a developed counter-discourse, a critical calling of the past into the present' ${ }^{\prime 18}$ These ideas linked to memory narrative production and negotiation within the nation are central to the research presented in this paper, yet, in this case they are applied to how the Malvinas War is remembered in national and local narratives.

Initiated by the dictatorship in 1982, the war and its subsequent remembrance have received scant attention in comparison to state repression which took place within mainland Argentina between 1976 and $1983 .{ }^{19}$ Commemoration of the Malvinas War has been considered sensitive, most especially in the immediate post-dictatorial era, given the widely discredited status of the armed forces. Argentine society has been faced with a complex dilemma that centres on how to commemorate a war (with all the patriotic sentiment it arouses) instigated by a regime that was also repressing its own civilians. ${ }^{20}$ In this sense, researching the Malvinas War is not a neutral act either and Lorenz has referred to the suspicion of respondents who questioned whether his focus on the Malvinas, as opposed to state terrorism, reflected his tacit support for the military. ${ }^{21}$ Notwithstanding these challenges, Guber has explored the memory politics associated with the 'official' Malvinas War monument in Retiro, Buenos Aires, shedding light on contestations between diverse

\footnotetext{
${ }^{17}$ Elizabeth Jelin, State Repression and the Struggles of Memory (London: Latin America Bureau, 2003); Daniel Friedrich, 'The Memoryscape in Buenos Aires: Representation, Memory, and Pedagogy', Cultural Studies, 27 (2011), pp. 171-89.

18 Bell, 'Afterword', p. 214.

${ }^{19}$ Osvaldo Bayer, Atilio A. Boron and Julio C. Gambina, El terrorismo de estado en la argentina: apuntes sobre su historia y sus consecuencias (Buenos Aires: Instituto Espacio para la Memoria, 2010).

${ }^{20}$ Federico Lorenz, 'Se habla de Malvinas al estilo “Billiken”', Página/12, 19 June 2011.

${ }^{21}$ Federico Lorenz, Las guerras por Malvinas.
} 
interest groups (i.e. families of fallen soldiers and the state) over its design and location. ${ }^{22}$ Her work has also sought to tease out the different ways in which the armed forces (comprising the air force, army and navy) remember the Malvinas War through her research with Argentine Air Force personnel. ${ }^{23}$ Lorenz has written extensively about the Malvinas, most notably charting the experiences of veterans and how they fit into wider societal narratives of remembering the 1982 war in Argentina. ${ }^{24}$ More recently, he has provided critical commentary on the Malvinas museum, inaugurated in 2014 and situated within the grounds of the ex-naval school (or la ex-ESMA, itself a site synonymous with state repression), in the northern suburbs of Buenos Aires. ${ }^{25}$

These studies, then, have largely focused on memory narratives and their representation at the national level as opposed to exploring how and crucially why they might be interpreted, re-worked or reproduced in different localities. ${ }^{26}$ As Crenzel points out, in relation to the broader interrogation of memory in Argentina, it is 'the local and popular representations and memories' which have often been bypassed. ${ }^{27}$ He claims that these regional cleavages are 'particularly relevant given the deepening, since the dictatorship, of social inequalities and regional fractures in the country'. ${ }^{28}$ They are also important to explore, I would contend, because of geographical differences in how state repression was enacted and

\footnotetext{
${ }^{22}$ Guber, ¿Por qué Malvinas?

${ }^{23}$ Rosana Guber, 'Bautismo de fuego y gracia de Dios. Las bellas memorias aeronáuticas de la guerra de Malvinas', Tabula Rasa, 6 (2007), pp. 221-62.

${ }^{24}$ Lorenz, Las guerras por Malvinas. The terms conscript and veteran are used interchangeably in this paper. Most crucially, they are distinguishable from officers (i.e. senior members of the military dictatorship) because their military service was obligatory. For more on the contested nature of these definitions see Lorenz, Las guerras por Malvinas.

${ }^{25}$ Federico Lorenz, 'Visita a un sentimiento nacional', available at http://www.perfil.com/contenidos/2014/07/25/noticia 0055.html (last accessed 10 October 2014).

${ }^{26}$ David Atkinson, 'Kitsch Geographies and the Everyday Spaces of Social Memory', Environment and Planning A, 39 (2007), pp. 521-40.

${ }^{27}$ Emilio Crenzel, 'The Memories of the Disappeared in Argentina', in Gabriele Andreozzi (ed.), Desaparicion: Argentina's human rights trials (Oxford: Peter Lang AG) p. 296.

${ }^{28} \mathrm{lbid}, \mathrm{p} .296$.
} 
experienced (between urban centres and the interior of the country, for example). Just as memories of state repression and disappearance are regionally variable, those connected to the Malvinas War are equally so. Commemorative narratives related to the war are produced locally throughout Argentina in ways which can reproduce, complement, and/or disrupt dominant national discourse. ${ }^{29}$ There were subtle differences, silences and localised specificities within the memory narratives circulated in school classrooms in my research and the reasons for these divergences from national narratives are explored..$^{30}$

Recent work on the sociology of collective memory has interrogated when and under what conditions transformations of collective memory might occur. These advances are useful for conceptualising the question of when local memories might reframe or reinforce national narratives. Misztal and Conway both cite the importance of considering the actors (elite and non-elite), context and temporality associated with specific constructions of memory. ${ }^{31}$ Thus, the 'success of memory work depends on the resonance and connection to socialpolitical-institutional contexts', which can vary temporally as well as spatially (e.g. between global, national and local scales) and, 'requires human actors to make it pertinent to specific social and political contexts' ${ }^{32}$ Critical here is the acknowledgement that collective memory is not neutral and bound up with wider socio-political power struggles and sensitivities. So, for instance, while remembering the Malvinas War has been brought into more recent state political projects focusing on human rights and memory in Argentina (since 2003), this was not always the case and has varied with different administrations since the advent of

\footnotetext{
${ }^{29}$ Stephen Legg, 'Reviewing Geographies of Memory/Forgetting', Environment and Planning A, 39 (2007), p. 456-66; Tabar, 'Memory, Agency, Counter-Narrative'.

${ }^{30}$ Tabar, 'Memory, Agency, Counter-Narrative', p. 15. Bellino, 'Whose Past', p. 138.

${ }^{31}$ Barbara A. Misztal, Theories of social remembering (Maidenhead: Open University Press, 2003); Brian Conway, Commemoration and Bloody Sunday: pathways of memory (Basingstoke: Palgrave Macmillan, 2010).

${ }^{32}$ Conway, Commemoration and Bloody Sunday, p. 149.
} 
democracy. ${ }^{33}$ Its commemoration in different parts of the country is also inflected by local context and the actors implicated (i.e. how the war affected the locality in question, as well as the presence/absence and influence of key actors such as past and present members of the armed forces).

Through his research on collective memory transformations in the United States, Ghoshal identifies what he defines as 'mnemonic opportunity structures' which affect the success of commemorative initiatives in different cities. $^{34}$ These encompass the cultural and institutional conditions which shape a city's commemorative capacity (what Conway and Misztal might define as context), but also the moral valence of the actors involved. Ghoshal states that, 'the moral standing of key characters at the time these stories are recorded impacts the fates of related memory projects'. ${ }^{35}$ There were certain moral ambivalences inherent to commemorating actors involved in the Malvinas War which affected how teachers in Río Gallegos felt able to remember the event in the classroom. The war involved professional officers who were closely associated with the military regime and potentially state terror, as well as conscripts who were largely considered innocent. The heavy presence of the armed forces in the city of Río Gallegos (discussed below) meant that many young people attending schools had members of their family who had professional associations with the military, which influenced how teachers discussed and commemorated the war.

\footnotetext{
${ }^{33}$ Guber, ¿Por qué Malvinas?

${ }^{34}$ Raj A. Ghoshal, 'Transforming collective memory: mnemonic opportunity structures and the outcomes of racial violence memory movements', Theory and Society, 42 (2013), pp. 329-50.

$35 \mathrm{Ibid}$, p. 338. For a similar discussion of reputational trajectories and valence in memory projects in Latin American contexts see, Robert S. Jansen, 'Resurrection and Appropriation: reputational trajectories, memory work, and the political use of historical figures', American Journal of Sociology, 112 (200\&), pp. 953-1007.
} 
Everyday spaces have attracted increasing interest in studies of nationalism and collective memory to better understand how such discourses are (re)produced throughout society. ${ }^{36}$ This work has often used schooling as an entry-point to exploring the formation of national citizens, as well as the ways in which historical events are remembered in the classroom. ${ }^{37}$ Vom Hau's research in Argentina, Mexico and Peru is illustrative here, underlining how war commemoration has been historically represented in school textbooks and through school ceremonies. ${ }^{38}$ Friedrich has highlighted the notion of historical consciousness within school textbooks focused on the last dictatorship in Argentina, and its role in the building of an Argentine democratic citizenry. ${ }^{39}$ As he points out, these encourage students to identify with the 'correct' moral lessons from the past, determining what can and cannot be said about sensitive historical events in ways which shut down opportunities for more critical classroom discussion. ${ }^{40}$ And yet, these examples are also symptomatic of how this research has tended to look at such narratives in a reductionist manner, focusing on teaching curricula, ceremonies, textbooks and representations therein. ${ }^{41}$ This has left little room for

\footnotetext{
36 Atkinson, 'Kitsch Geographies'; Michael Billig, Banal Nationalism (London: Sage, 1995); Tim Edensor, National Identity, Popular Culture and Everyday Life Oxford: Berg, 2002); Noah W. Sobe, 'Textbooks, Schools, Memory, and the Technologies of National Imaginaries', in James H. Williams (ed.) (Re)Constructing Memory: School Textbooks and the Imagination of the Nation (Rotterdam: Sense Publishers, 2014), pp. 313-18.

${ }^{37}$ Keith A. Crawford and Stuart J. Foster, War, Nation, Memory: International Perspectives on World War II in School History Textbooks (Charlotte, NC: IAP, 2007); Carlos Escudé, 'Argentine Territorial Nationalism', Journal of Latin American Studies, 20 (1988), pp. 139-65; Ian Grosvenor, “There's No Place Like Home”: Education and the Making of National Identity', History of Education: Journal of the History of Education Society, 23 (1999), pp. 235-50; Jonathan Scourfield, Bella Dicks, Mark Drakeford, Andrew Davies, Children, Place and Identity: Nation and Locality in Middle Childhood (London: Routledge, 2006); James H. Williams (ed.) (Re)Constructing Memory: School Textbooks and the Imagination of the Nation (Rotterdam: Sense Publishers, 2014).

38 Matthias Vom Hau, 'Nationalism and War Commemoration - a Latin American Exceptionalism?' Nations and Nationalism, 19 (2013), pp. 146-66.

${ }^{39}$ Daniel S. Friedrich, 'The Mobilization of Historical Consciousness in the Narratives about the Last Argentine Dictatorship', in James H. Williams (ed.) (Re)Constructing Memory: School Textbooks and the Imagination of the Nation (Rotterdam: Sense Publishers, 2014), pp. 13-34.

${ }^{40}$ Scholars have explored the challenges of teaching other emotive and complex subjects such as the Holocaust. See, for example, Stuart Foster, 'Teaching about the Holocaust in English Schools: Challenges and Possibilities, Intercultural Education, 24 (2013), pp. 133-48.

${ }^{41}$ Carlos Escudé, Patología del nacionalismo: el caso argentino (Buenos Aires, Instituto Torcuato Di Tella, 1987); Grosvenor, “'There's No Place Like Home"'; Haggay Ram, 'The Immemorial Iranian Nation? School
} 
understanding how narratives emanating from the state might have been received, resisted, performed and reproduced by institutions, teachers and other individuals working within schools, as well as young people themselves. ${ }^{42}$ It has also served to reify the national as the scale at which commemoration is uniformly produced and enacted within schools.

The research presented in this paper builds on emerging work on the negotiation of state memory within educational settings, by focusing on the perspectives of teaching staff and other actors involved in the classroom. Faden, through her research on World War II narratives in classrooms in the US and Canada, shows how 'teachers have the power to reinforce, challenge, or complicate the story of the nation as told in textbooks'. ${ }^{43}$ The teachers involved in her study negotiated conflicting visions of the nation in ways which belied simple reproductions of narratives within textbooks or those stemming from their personal beliefs. In a very different context, Bellino has explored memory narratives of the civil conflict in Guatemala, 'drawing on the voices of educators and parents to explain their preferences, challenges, and practices in transmitting the past to the postwar generation' ${ }^{44}$ In particular, her contribution sheds light on the ways in which critical discussion of the civil conflict is silenced in formal educational settings for fear of 'opening wounds' and is more likely to surface informally through intergenerational exchanges with family members. Teachers in Bellino's research often saw the use of textbooks as a 'safer' strategy for interrogating historical events in Guatemala, as they were unsure about the extent to which students and their families might have been affected by the civil conflict. These studies,

Textbooks and Historical Memory in Post-Revolutionary Iran', Nations and Nationalism, 6 (2000), pp. 67-90; Scourfield et al., Children, Place and Identity.

${ }^{42}$ The research presented in this paper is from the first stage of a larger project which sought to understand the ways in which the Malvinas is taught in Argentine schools from the perspective of politicians, officials and teachers. The next part of the research will work alongside young people in order to understand how they perceive commemoration of the Malvinas War and the sovereignty question more generally.

43 Faden, 'History Teachers Imagining', p. 191.

${ }^{44}$ Bellino, 'Whose Past', p. 133. 
then, are a critical reminder that 'schools need to be considered important sites of production and not simply sites of reproduction' when considering narratives of memory and their formation. ${ }^{45}$

For the commemoration of the Malvinas War and more recent events the incorporation of teachers' perspectives is made practically possible through interviews. However, for the historical studies of Vom Hau and Escudé it is more difficult to gauge the reception and use of teaching resources within schools. Notwithstanding the challenges, research has shown how archival sources, retrospective interviewing, diaries written by teaching staff and annotations and/or alterations made to textbooks can proffer clues as to the historical reception of teaching resources. ${ }^{46}$ Hence, Bhattacharya, is able to show how in 1960s Indian schooling, 'teachers in different regions read the textbooks...in their own ways, reworking their meanings, introducing their own interpretations, eliminating chapters, adding anecdotes, and in the process transforming the texts' ${ }^{47}$ In an Argentine context, Vom Hau shows how teachers were resistant to Peronist textbooks that became commonplace throughout classrooms in Argentina during the 1940 s. ${ }^{48}$ Interestingly, their resistance did not always result in outright refusal to use the resources but on more subtle negotiations of the educational resources provided by the state. So, for example, textbooks might be used as sparingly as possible during classes or simply for grammar exercises in place of engaging with their inherent ideological content and notions of nationhood.

\footnotetext{
${ }^{45}$ Sobe, 'Textbooks, Schools, Memory', p. 313.

${ }^{46}$ Neeladri Bhattacharya, 'Teaching History in Schools: the Politics of Textbooks in India', History Workshop Journal, 67 (2009), pp. 99-110.

47 Ibid, p. 101.

48 Matthias Vom Hau, 'Unpacking the School: Textbooks, Teachers, and the Construction of Nationhood in Mexico, Argentina, and Peru', Latin American Research Review, 44 (2009), pp. 127-54.
} 
To understand how memory is variously interrogated within educational contexts throughout Argentina in the present-day, it is necessary to highlight the 'decentralisation' of the national education system which took place in the $1990 \mathrm{~s} .{ }^{49}$ The move from a centralised to a federal educational system meant that provincial authorities had far greater autonomy with regards to determining the school curriculum. ${ }^{50}$ While the national education ministry continues to produce teaching resources focusing on memory and the Malvinas, for instance, their use in classrooms is not obligatory and can be determined by their reception at the provincial or institutional level. ${ }^{51}$ The Malvinas War itself was predominantly studied and remembered in classes on national history and school ceremonies linked to the anniversary of the islands' 'recuperation' (i.e. the $2^{\text {nd }}$ of April or Día del Veterano $y$ de los Caídos en la Guerra de Malvinas which is a national holiday in Argentina), hence my study prioritised the recruitment of history teachers specifically. This is not to suggest that the Malvinas is absent from other disciplines as it did feature in geography and civic education classes.

My research engages with teaching staff to understand how memory narratives associated with the Malvinas War might shift between national and local scales, but it also goes further to consider other actors (such as war veterans and local residents in Río Gallegos) who engaged with schools. Grosvenor states that, 'we need to extend our vision of schooling to consider the cumulative effect of value messages in both the formal and "hidden curriculum"...In other words, our research agenda should be widened to embrace the

\footnotetext{
${ }^{49}$ Diana Milstein, 'Un nuevo desafío: sobrevivir a la transformación educativa', Cuadernos FHYCS-UNJu, 22 (2004), pp. 11-21.

50 Graciela Krichesky and Karina Benchimol, La educación argentina en democracia: transformaciones, problemas y desafíos de una escuela fragmentada (Buenos Aires: Biblioteca Nacional, 2008).

${ }^{51}$ Ana Pereyra, La relación de los adolescentes con la historia reciente de Argentina. Un studio exploratorio de la conciencia histórica entre estudiantes de escuelas medias públicas de la ciudad de Buenos Aires (Buenos Aires: FLACSO, 2007).
} 
grammar and the "choreography", the routines and the rituals, and the symbolic events of everyday schooling'. ${ }^{52}$ In keeping with these ideas, my research takes an interest in the 'unofficial' (in terms of their absence in state curriculums) ways of remembering which took place in schools which are not captured by reading official state textbooks on the Malvinas. ${ }^{53}$ These memories were unquestionably shaped by the experiences, histories and sensitivities of local people in Río Gallegos, a city with intimate connections to the 1982 war.

\section{Remembering the Malvinas War in Argentina and Río Gallegos}

The Malvinas War has only acquired a prominent position within narratives of Argentine state memory relatively recently. Indeed, in 2012, state restrictions were finally lifted on the Informe Rattenbach, which enabled the public to view a government-commissioned report published in 1983, evaluating the role of the armed forces during the war. In 2014 a government-funded museum opened in Buenos Aires dedicated to the history and geography of the Malvinas (i.e. not only focusing on the war and its memory), further reiterating the centrality of the issue to the Argentine state.${ }^{54}$ The resurgence of sentiment for the Malvinas has been attributed in part to the Patagonian roots of the late Néstor Kirchner who served as Argentina's president from 2003-2007. He insisted 'that the geographical limits of the nation were not, as so many Argentines seemed to think, that of Capital Federal [the city of Buenos Aires], but of Las Malvinas'. ${ }^{55}$ Since 1994 the Argentine Constitution has declared the Malvinas and neighbouring territories in the south Atlantic and Antarctica integral parts of the nation and more specifically the southernmost province

\footnotetext{
52 Grosvenor, “"There's No Place Like Home”', p. 248.

53 Bellino, 'Whose Past'.

54 BBC News, 'Argentina to open Falklands museum, says Fernández' available at http://www.bbc.co.uk/news/world-latin-america-17267714 (last accessed 14 November 2013).

55 James Scorer, 'From la guerra sucia to “A Gentleman's Fight': War, Disappearance and Nation in the 19761983 Argentine Dictatorship', Bulletin of Latin American Research, 27 (2008), pp. 58.
} 
of Tierra del Fuego; categorisations that are unsurprisingly rejected by the Falkland Islands and British governments. State-produced maps and discourses relating to the Malvinas had been in evidence in Argentina with varying degrees of intensity long before the presidency of Néstor Kirchner. ${ }^{56}$ The fact that the current President Cristina Fernández de Kirchner continues to spend considerable time in various residences in Santa Cruz province, including Río Gallegos, continues this tradition of presidential connection to the south Atlantic.

The localised perspectives presented in this paper are drawn from research undertaken in the austral city of Río Gallegos. The city, situated in the sparsely populated Patagonian province of Santa Cruz, now has a population of nearly 100,000 according to the last census undertaken by INDEC in 2010, and this figure has more than doubled since the 1980s due to economic advancements and incentives offered to state employees in particular. ${ }^{57}$ This is a region with an extensive history of connection to the Malvinas (situated approximately 400 miles to the east of the Argentine mainland) stretching back to the $1880 \mathrm{~s} .{ }^{58}$ These connections with the Malvinas were most evident in the port cities of Santa Cruz province which witnessed migration, and facilitated the exchange of livestock, agricultural equipment and expertise. Families and those working in agriculture in cities like San Julián and Río Gallegos maintained strong relations with the Malvinas over the course of the next century until the outbreak of the war in $1982 .{ }^{59}$

\footnotetext{
${ }^{56}$ Escudé, 'Argentine Territorial Nationalism'.

57 INDEC, Censo 2010 available at http://www.sig.indec.gov.ar/censo2010/ (last accessed 10 October 2014).

58 Milagros Pierini and Pablo Gustavo Beecher, Cien años del Club Británico de Río Gallegos: los británicos en Santa Cruz (Río Gallegos: Club Británico de Río Gallegos, 2011).

${ }^{59}$ Andrew Graham-Yooll, La colonia olvidada: tres siglos de habla inglesa en la Argentina (Buenos Aires: Emecé Editores, 2007); Michael Mulhall, The English in South America (Buenos Ayres: Standard Office, 1878); Glyn Williams, The Welsh in Patagonia: the State and the Ethnic Community (Cardiff: University of Wales Press, 1991).
} 
The war was a particularly painful episode for communities in these austral cities and the islands themselves, abruptly ending familial, commercial and socio-cultural relations that had developed over many years. ${ }^{60}$ Research has hinted at the ways in which people's views about the Malvinas sovereignty question can vary according to a number of different factors including geographical location. ${ }^{61}$ It is perhaps unsurprising that identifications with the islands in a place like Río Gallegos are more entrenched and intimate than say in the capital Buenos Aires given the extent of these historical ties. ${ }^{62}$ The war was another chapter which extended and ultimately ended this history of association in deeply traumatic ways, primarily for the communities that lived in the city during $1982 .{ }^{63}$ The city, which hosted a large airbase and army unit, was situated in an already intensely militarised region as a consequence of border disputes with neighbouring Chile in the late 1970s and these tensions were still apparent in the early 1980s. ${ }^{64}$ Many of the adults involved in this research had vivid memories of the Malvinas War and its impact on the city. People who had been resident there at the time regularly cited anecdotes drawn from their war-time experiences which included, for instance, watching Argentine Air Force jets depart from and return to the airbase in Río Gallegos, counting to see whether airframes and as a consequence aircrew had been lost in action. Daily life was closely intertwined with the military before and after the war and most overtly when hostilities broke out in and over the islands in early May 1982. The air raid drills and blackouts, which were a frequent

\footnotetext{
60 Pierini and Beecher, Cien años del Club Británico.

${ }^{61}$ Benwell and Dodds, 'Argentine Territorial Nationalism'.

${ }^{62}$ Milagros Pierini and Pablo Gustavo Beecher, 'Malvinas y Santa Cruz: una relación histórica quebrada por una guerra', Malvinas en la Universidad: concurso de ensayos (Buenos Aires: Ministerio de Educación de la Nación, 2012).

63 The president made reference to her memories of living in Río Gallegos during the 1982 war in a speech in Ushuaia on the $2^{\text {nd }}$ of April 2015.

${ }^{64}$ Lorenz, Las guerras por Malvinas.
} 
reminder of the potential for the city to be targeted by British bombers or Chilean intelligence units, were also remembered during interviews and informal conversations.

\section{State educational narratives of the Malvinas War}

The formulation of contemporary state educational narratives on memory of the Malvinas War can be contextualised by briefly referencing the changing nature of national commemorations related to the events of 1982. Anniversaries associated with the war have not always been marked with the same enthusiasm by Argentine governments post-1982 as Lorenz has shown. ${ }^{65}$ In the immediate aftermath of the war, President Alfonsín was reluctant to initiate any national ceremonies which might serve to restore the military's credibility in an emerging democratic society. This has changed markedly in the interim and most especially during the presidential terms of the Kirchners from 2003-2015. The $2^{\text {nd }}$ of April is now typically marked with a national ceremony that features high profile speeches from the president broadcast live across all national television networks. In the last five years President Fernández de Kirchner has chosen to deliver her speech in cities throughout Patagonia including Ushuaia, Río Gallegos and Puerto Madryn (similar, albeit usually smaller, commemorative ceremonies are held in cities and towns throughout Argentina). These speeches vary each year but often make a point of honouring the 'heroes' of the war, whilst reaffirming Argentina's 'imprescriptible' sovereignty rights over the Malvinas by referring to historical arguments stretching back far beyond 1982 . They also position the war within the context of state terrorism, juxtaposing the heroic actions of young conscripts with the abuses they suffered at the hands of their superiors. In 2015 President Fernández de

\footnotetext{
${ }^{65}$ Lorenz, Las guerras por Malvinas.
} 
Kirchner used the anniversary to announce the creation of a national oral archive for the Malvinas, restating once again the importance of the war in official memory narratives.

In 2005 Argentina's Ministry of Education inaugurated a unit dedicated to memory (Educación y Memoria), producing educational resources which initially focused on the last dictatorship in Argentina, and then, a few years later, the Malvinas War and the Holocaust. Here, I reflect on interviews conducted with officials working at the education ministry and my analysis of nationally-circulated teaching materials, to think through some of the main threads of official/national narratives about the Malvinas War. One of the most prominent points evident from these sources, and echoed in contemporary state narratives, was that remembering the Malvinas was about far more than 1982 alone:66

'For many years the Malvinas was only the war, with everything that this implicated...Of course the war is a very important part, very painful, 649 deaths, more than 400 ex-soldiers that have committed suicide, all of this represents an enormous wound for the Argentine people. Today our approach takes into account the war, but in dialogue with a perspective which is more global, that includes the history going back over a longer period, the diplomatic dispute and that connects with the economic and strategic issues, in line with the complaint about the pillage of the natural resources and the militarisation of the islands by Great Britain. Today, definitively, there is a way of looking at the Malvinas which is much wider than before' ${ }^{67}$

\footnotetext{
${ }^{66}$ Pensar Malvinas: una selección de fuentes documentales, testimoniales, ficcionales y fotográficas para trabajar en el aula (Buenos Aires: Ministerio de Educación de la Nación, 2009). For example, the Malvinas museum in Buenos Aires consciously avoids associating the Malvinas with the 1982 war exclusively and focuses on other historical events crucial to Argentina's sovereignty claim, as well as the islands' fauna and flora.

${ }^{67}$ Interview with Alberto Sileoni, Minister of Education for the Nation, Buenos Aires, 25 March 2013.
} 
The efforts to acknowledge the longevity of Argentina's historical links to the Malvinas, and the modern-day implications of British 'occupation' of the islands are, of course, important aspects of the nation's sovereignty claim which are frequently recited at diplomatic meetings such as those held at the UN. This is mirrored in educational narratives linked to the Malvinas at the national level. So, remembering the Malvinas is no longer restricted to a consideration of the losses and trauma associated with the 1982 war alone, and should also incorporate memories of territorial loss in 1833, as well as the ongoing resource and economic implications of British 'occupation'. As with constructing all narratives of memory, there are inherent sensitivities and the state has been very careful to ensure that the war and the sacrifices of veterans still feature prominently (to, among other things, appease veterans' organisations), yet crucially, not at the expense of considering wider historical and contemporary events.

This is connected to the second significant national Malvinas narrative, which calls for the war to be situated within the context of domestic politics in Argentina in the early 1980s. This encourages provincial educational ministries, schools and teaching staff to avoid looking at the war in isolation as a discrete chapter in Argentine history, but one intimately linked to the dictatorship and broader notions of state terror:

'The line that the team [Educación y Memoria] has followed since we took on the Malvinas issue is to think about the Malvinas War within the context of the last military dictatorship, within the context of state terror. For us, you cannot explain this war if you don't take into account the political context in which our country was living' ${ }^{68}$

\footnotetext{
${ }^{68}$ Interview with an education official at Argentina's Ministry of Education, Equipo Educación y Memoría, 20 March 2013.
} 
Linking the Malvinas with the politics of memory that the Argentine state has sustained in the last decade was seen by officials working at the national ministry as one of the most important recent developments in memory narratives related to the war. However, emphasising the relationship between the dictatorship and the Malvinas was fraught with its own historical sensitivities as the same official outlined:

'The Malvinas became extremely problematic for Argentine politics [in the years following the war] because it had had been associated with the military dictatorship or with military officers; with all the problems that this generated for veterans trying to get social recognition because they were left identified with the dictatorship. Somehow, today, we can look at it in another way which doesn't reduce the Malvinas to the dictatorship, but equally doesn't stop thinking about this historical context'.

The sense here was that enough time had now passed for Argentine society and schools to begin to understand the nuances and contradictions bound up with the Malvinas War. ${ }^{69}$ Whereas previously (from directly after the war, into the 1990s) the veterans (and the wider Malvinas cause) had been pejoratively labelled through their associations with a war instigated by the dictatorship, now the context of state terror could and should be acknowledged in ways which made distinctions between, for instance, conscripts and officers; Argentina's 'just' sovereignty claim to the Malvinas and the illegitimacy of the regime..$^{70}$ In other words, the national narrative was encouraging provincial educational authorities and schools to remember the Malvinas War alongside state terrorism in ways which teased out some of these complex questions.

Remembering the Malvinas locally: living the war in Río Gallegos

\footnotetext{
${ }^{69}$ Although see Lorenz, 'Se habla de Malvinas'.

${ }^{70}$ Lorenz, Las guerras por Malvinas.
} 
'What happens at the national level [in terms of discourses about the Malvinas War] is one thing but you have to see how this reverberates or how it arrives at the school, as although the politics are national, the schools are provincial, the ministers are provincial and the curriculum as well' ${ }^{71}$

This quote from a history teacher in a secondary school in Río Gallegos begins to hint at the importance of being sensitive to educational and commemorative narratives produced at the local level, which may or may not subscribe to those disseminated nationally. ${ }^{72}$ This is especially pertinent given the political organisation of the education system in Argentina, where the national ministry produces basic guidelines which leave considerable scope for provincial educational authorities, and indeed individual institutions, to determine curriculum content. Decisions about the curriculum and the relative emphasis placed on different topics such as the Malvinas or the last dictatorship and state terrorism can, in turn, be shaped by localised histories and the politics of memory. ${ }^{73}$

Local narratives of memory related to the Malvinas shaped the content of teaching resources and activities produced by provincial educational staff in Santa Cruz and schools in Río Gallegos. Whereas national narratives were encouraging a broader historical focus, moving away from an exclusive interest in the 1982 Malvinas War, the localised histories connected to the war in Río Gallegos were pervasive and influential in determining how it was presented to young people in the classroom. ${ }^{74}$ An illustrative example was an online teaching resource about the Malvinas War being developed by staff at the provincial education ministry as my research was being undertaken. An education official working on

\footnotetext{
${ }^{71}$ Interview with a public secondary school history teacher, Río Gallegos, 3 March 2013.

72 Jelin and Kaufman, 'Layers of Memory'; Sobe, 'Textbooks, Schools, Memory'.

73 Tabar, 'Memory, Agency, Counter-Narrative'; Vom Hau, 'Nationalism and war commemoration'.

74 Legg, 'Reviewing Geographies'.
} 
the project entitled Setenta y cuatro días or 74 days (the number of days of the 1982 war) explained its rationale:

'The objective is the construction of social memory about what the Malvinas means in Santa Cruz, or what the Malvinas means for those who live in this province. First this goes back to...looking at the meaning [of the war] in terms of the society we had here in Santa Cruz in '82...In this project the Malvinas are not analysed from the military point of view; that is included from a contextual angle, it's necessary to include it but what we work with here are multi-perspectives. What happened to those people that were present in Santa Cruz in this period? We believe that this is the way to honour those who gave their lives, to those who were actually more closely affected. In reality it's an event that marked everyone who was in the territories [Santa Cruz and the Malvinas] in $1982^{\prime} .{ }^{75}$

In this quotation, then, the meaning of the Malvinas in Santa Cruz is explicitly linked to the war. The website presents memory as 'multidirectional' through the testimonies of citizens, journalists and others who were present at the time of the war (alongside those of veterans), to give a sense of how it was lived in Río Gallegos and other cities in Santa Cruz. ${ }^{76}$ These accounts consider the consequences of the war in the urban spaces of Santa Cruz; environments that young people are familiar with and this familiarity is used as a means to try and spark interest about an issue that might otherwise be considered (temporally and spatially) distant, relative to their everyday lives. In contrast to national memory narratives of the Malvinas which were increasingly looking beyond 1982, this teaching resource drew

\footnotetext{
${ }^{75}$ Interview with an education official at the Provincial Office of Higher Education, Santa Cruz, Río Gallegos, 6 March 2013.

${ }^{76}$ Rothberg, Multidirectional Memory; Legg, 'Reviewing Geographies'.
} 
on the recent history of the war and its relationship to local urban space to make the past meaningful to students. ${ }^{77}$

Many teachers talked about the challenge of retaining the interest of young people when discussing the Malvinas in the classroom, partly as a result of this sense of disconnection to historical events that occurred before they were born. To counter this, teachers often asked their students to examine the personal war-time memories of older family members for school assignments:

'You have to make the connection with local history for them. You have to make them go into the local history...Where was your father [during the Malvinas War]? Then the testimonies of their parents start to come up. So, prior to the class the student listens to the testimony of their father, then, for that student the war is already embodied in someone, it's not that they see it on the television or in films; rather the war has been lived by their parents, their grandparents'.$^{78}$

Young people were encouraged to explore this local living archive through these testimonies, shaping how they learnt about the Malvinas War in ways which were clearly distinctive to what might be possible in other regions of the nation. ${ }^{79}$ There was a sense amongst the teachers interviewed that the war might as well be ancient history for their students and in an attempt to make it more pertinent and embodied it was remembered through the accounts of family members, as opposed to nationally-produced textbooks or documentaries: 'For the student it's a history that's so uninteresting like San

\footnotetext{
77 Jelin and Kaufman, 'Layers of Memory'.

78 Interview with a private secondary school history teacher, Río Gallegos, 15 March 2013.

${ }^{79}$ See Beatriz Sarlo, Tiempo pasado: cultura de la memoria y giro subjetivo. Una discusión (Buenos Aires: Siglo XXI Editores, 2005); Friedrich, 'The Mobilization of Historical Consciousness'.
} 
Martín...because it's another chapter of history if you don't connect it to their everyday life. $^{80}$

Thus, young people's exposure to memories of the Malvinas War spilled over into spaces outside of the classroom, resembling the fluidity and multi-sited nature of social memory cited by Atkinson and others. ${ }^{81}$ Young people entered into conversations with older family members and friends and looked at material objects with them such as magazines, newspapers and other mementos from the era in order to understand more about the Malvinas War and its impact on the city of Río Gallegos. These personal memories of the war as lived in Río Gallegos were accessed outside of institutional space, but adults also entered the school to take part in specially arranged events:

'Last year, do you know what they did in the college? What they did was invite a group of people that lived in Río Gallegos during the war. I think there was a mathematics teacher who spoke about her experience; she talked about how she was an adolescent and how she lived the war. The thing that I told you about the [bombing raid] simulations. Also there was another woman who spoke about how she was going along in her car and suddenly everything went dark and she was left in the middle of the street with her children. And well, they went on telling you what they went through at this time' ${ }^{82}$

While teaching staff and resources such as textbooks might traditionally receive the bulk of attention when exploring the production of social memory in schools, such approaches tend to miss the influence other adults and material objects can have inside and outside institutional space. Adults from the community, both family members and those involved in

\footnotetext{
${ }^{80}$ Interview with a private secondary school history teacher, Río Gallegos, 15 March 2013.

${ }^{81}$ Atkinson, 'Kitsch Geographies'; Rothberg, Multidirectional memory.

82 Interview with a public secondary school history teacher, Río Gallegos, 11 March 2013.
} 
the kinds of events described here, were a fundamental part of the production of social memory within schools in Río Gallegos. ${ }^{83}$ This brought about slightly different ways to remember the war which did not necessarily prioritise the heroic feats of conscripts, who feature prominently within national narratives. ${ }^{84}$ Instead, getting a sense of the fears and related emotions of the 'everyday' citizenry living in Río Gallegos gave exposure to experiences of warfare which were likely to differ from those of individuals involved in the military campaign. These underscored the vulnerability and anxiety felt by many people living in the city during the months of the war.

Recollections of the Malvinas War are typically gendered, dominated by commemoration of the experiences of young conscripts presented to students in person, or recorded through diaries and letters sent to the Argentine mainland in 1982 (see next section)..$^{85}$ Interestingly, localised framings of the war evident in online teaching resources, school projects and events create space for other voices to be heard. These relay accounts of the war as lived through spaces of the family, home and community, and while they may reinforce binaries regarding the gendering of space and performance, they nevertheless make visible the broader societal impacts of this deeply troubling event for the city. As teaching staff made clear, it was these kinds of activities and events that stimulated young people most. Hence, first-hand stories of people having to shelter under school desks during simulated bombing raids and associated accounts of life in Río Gallegos during the war were drawn on by teachers wherever possible.

\footnotetext{
83 Bellino, 'Whose Past'.

${ }^{84}$ The film Iluminados por el fuego directed by Tristán Bauer (2005) is a graphic depiction of the experiences of conscripts in the Islands and is now distributed by the Ministerio de Educación de la Nación as a DVD.

85 Also observed in the research of Brian Graham and Yvonne Whelan, 'The Legacies of the Dead: Commemorating the Troubles in Northern Ireland', Environment and Planning D: Society and Space, 25 (2007), pp. 476-95. For an example of extracts from diaries written by conscripts see, Leonardo Abrahan, Diario de Malvinas (Buenos Aires: Editorial Dunken, 2006).
} 
Communities in the north of Argentina would not have lived the war with the same immediacy as those in the south, yet the war also left deep scars on towns and cities from where young conscripts originated. ${ }^{86}$ The minister of education for Argentina pointed out why communities in other regions a long way from the south Atlantic might have reason to remember and commemorate the war with similar levels of intimacy:

'In other regions of the country the impact of the war was notable. For example, I'm thinking about the province of Corrientes, the provinces in the northeast and northwest of Argentina that sent lots of young men to the war...so there the feeling also is very important and deep. Anyway, the Malvinas, and not only the war, live on in the distinctive popular memories that make up this country, from the north to the south' ${ }^{87}$

My case study from Río Gallegos shows that the immediate exposure of the city's population to the Malvinas War was crucial in shaping local memory narratives within schools. Elsewhere in Argentina, in northern provinces like Santa Fe, the Malvinas were also referenced most commonly in relation to the 1982 war (as opposed to history stretching further back). ${ }^{88}$ These connections with the war were emphasised primarily through the experiences of conscripts sent to fight who were from the local area (rather than the broader citizenry as was the case in Río Gallegos). Veterans regularly visited schools in Santa Fe to talk about the war and to take part in commemorative ceremonies, something common to cities and towns throughout Argentina which host centres for veterans (see next section). There was evidence that teaching staff in private and public schools in Santa Fe also personalised their teaching of the Malvinas war in the classroom. So, for instance, they

\footnotetext{
${ }^{86}$ See Lorenz, Las guerras por Malvinas.

${ }^{87}$ Interview with Alberto Sileoni, Minister of Education for the Nation, Buenos Aires, 25 March 2013.

88 These observations are based on short visits to several schools in the city of Santa Fe during March-April 2015.
} 
drew on their experiences of making clothing and sending chocolates or donations to support the young men sent to fight in 1982, as well as how it felt watching the war from a distance through state-manipulated media. ${ }^{89}$ Teachers in other cities far away from the South Atlantic, then, remembered the war in similarly intimate ways through these emotional and experiential accounts but in contrast to memory narratives in Río Gallegos, these tended to underscore the experiences of watching the war unfold from a distance. Of course, it must be acknowledged that the perspectives in this paper are drawn from a relatively small number of schools and not all institutions and teaching staff can be assumed to approach the teaching of the Malvinas in the same way across different regions. They do, nevertheless, point to the importance of considering national and local social-politicalinstitutional contexts and the multiple actors involved in memory work, to more effectively investigate when local remembering transforms and/or reproduces official memory narratives. ${ }^{90}$

One need not look to other provinces to find variations in how the Malvinas war is commemorated, as even within Río Gallegos there were notable differences in how institutions approached the issue. For instance, school assemblies dedicated to the Malvinas War and organised throughout Argentina on the school day nearest the $2^{\text {nd }}$ April, were not necessarily performed in the same way in institutions involved in this research:

'In the case of the Malvinas, in the public schools there are more constraints to follow the calendar of major national anniversaries, to follow the educational guidelines, therefore on this day [ ${ }^{\text {nd }}$ April] there will certainly be a school ceremony; something that doesn't occur, for example, in private secondary schools. I don't know about primary, but in the secondary

\footnotetext{
${ }^{89}$ Lorenz, Las guerras por Malvinas.

${ }^{90}$ Conway, Commemoration and Bloody Sunday; Faden, 'History Teachers Imagining'.
} 
school, we don't run things according to the national anniversaries, except in the morning when the coordinator gives the morning address and the issue is mentioned and nothing more. There is not a commemorative act here, in the public schools yes there are' ${ }^{\prime}{ }^{91}$

There was evidence that private and public schools marked the Malvinas War in distinctive ways. As this interviewee hints, the private school where she worked placed less emphasis on commemorative ceremonies related to the Malvinas war compared with their public counterparts (she had previously worked in a public school). The fact that the teacher interviewed here was from a bilingual (Spanish-English) school is significant when connected to the local histories of this part of Patagonia, with its relatively high ratio of residents of British descent (either from the UK or the Malvinas themselves). ${ }^{92}$ Pierini and Beecher point out that during the war, 'the descendants of the British settlers were felt to be subjects of the attacking nation, so their testimonies regarding their experience of that period are charged with sadness' ${ }^{93}$ Unsurprisingly, these memories are still raw for many adults of British descent and are indicative of why the Malvinas commemorations are downplayed within bilingual schools where they were more likely to have children enrolled. Memory, then, can help a community to collectively bring meaning to past events, but it can also expose 'moments of disaffection and suffering within that community'. ${ }^{94}$ Public schools organised formal commemorative assemblies which typically comprised speeches related to the Malvinas War and Argentina's ongoing sovereignty claim, as well as the singing of the Malvinas hymn and the national anthem. All schools were obliged to make reference to the

\footnotetext{
91 Interview with a private secondary school history teacher, Río Gallegos, 7 March 2013.

92 Andrew Graham-Yooll, La colonia olvidada.

93 Pierini and Beecher, Cien años del Club Británico, p. 261.

${ }^{94}$ Hodgkin and Radstone, 'Remembering suffering: trauma and history. Introduction', in Katharine Hodgkin and Susannah Radstone (eds.), Contested Pasts: The Politics of Memory (London: Routledge, 2003), pp. 97-103.
} 
Malvinas War in some way on the $2^{\text {nd }}$ of April but the ways in which they did so varied considerably.

\section{Negotiating military memories of the Malvinas and the dictatorship}

As noted above, the state is no longer framing the Malvinas War as an isolated event in its educational materials but part of a wider politics of memory enmeshed with histories of state terror. ${ }^{95}$ How does this ambition play out on the ground in a city like Río Gallegos which has strong socio-political histories connected to the military? What consequences has this had for the role of veterans of the war who often visit schools to talk about their experiences? Here I consider how institutions and teachers in Río Gallegos negotiated these memory narratives associated with the dictatorship and the Malvinas. Teaching staff were acutely aware of the city's connections to the military, both past and present, and the implications this had for whom might be present in their classes:

'Actually, I've always been very respectful. Even though I taught the subject of the dictatorship and I knew that I had lots of students who are children of military personnel, I tried to do it with respect. Because, well, one thing is like the military in a generic sense and another is when it's the father of this student. You can't say, "The people that serve in the military are all sons of bitches", because the student will say, "Hey, my father is involved in this". So, yes, to handle it with a bit of respect in relation to the student. The student is not to blame in the same way as the parents and in the majority of cases the military personnel from here [Río Gallegos and Santa Cruz more generally] were not involved in state terror' ${ }^{96}$

\footnotetext{
${ }^{95}$ Friedrich, 'The Mobilization of Historical Consciousness'.

${ }^{96}$ Interview with a private secondary school history teacher, Río Gallegos, 15 March 2013.
} 
This insight is significant because it hints at how teachers saw the need to adapt their teaching of recent national history as a direct result of the surrounding local environment; in this case the associations that Río Gallegos has had with the military. ${ }^{97}$ Although the military's presence in the city has been vastly reduced relative to the levels witnessed in the 1970s and 80s, the possibility that students had parents who had served or were currently serving in the armed forces was considered by teachers when they planned and delivered their classes. The nuances of state terror in terms of its impact across distinctive parts of the country are referred to in the final part of the quote, with the suggestion that those serving in the south of Argentina were more disconnected from these events relative to urban areas further north, like Buenos Aires and Córdoba. Importantly, this fact alongside the potential presence of young people with family in the armed forces was used as a reason to frame the (local) military in a less critical light, in ways which downplayed its links to state terror. It is a reminder that, 'Memory can challenge dominant interpretations of the past and stress the local and particular, although it must always remain dependent upon the power-knowledge relations in which it exists' ${ }^{98}$ The same teacher continued making links between the sensitivities of remembering the dictatorship and the Malvinas War:

'On the $24^{\text {th }}$ March [the national day of memory for truth and justice] you notice this group of people from the armed forces living alongside us with their children, who are our students. Yes, you can't be openly critical of the dictatorship. It depends as well, you see, each teacher in their classroom can do what they want...But the families get to hear the speeches in school assemblies and the governors are always worried that someone will come and complain about the speech, it's more difficult or rather, the dictatorship

\footnotetext{
${ }^{97}$ Cf. Bellino, 'Whose Past'.

${ }^{98}$ Stephen Legg, 'Memory and Nostalgia', Cultural Geographies, 11 (2004), pp. 99-107.
} 
continues to be a delicate topic. And the Malvinas War as well. If you invite a veteran, obviously you already know the profile of the school assembly, of the teacher that invited him and of the school governors who accepted that a veteran was going to be in the school'.

There was, then, a concern that members of the community associated with the military might be upset by the ways schools chose to remember the dictatorship or the Malvinas War. These sensitivities might also be expected in other parts of Argentina and are not necessarily unique to cities with the military profile of Río Gallegos. For instance, teaching staff may feel similar pressures in cities where veterans play an active role in how the Malvinas War is remembered within schools. Indeed, to placate these potential criticisms, many schools gave veterans a role in how the war was remembered and commemorated (most especially in early April when schools held assemblies dedicated to the topic). Moreover, the speeches and the photo montages shown at these school assemblies tended to circumvent overt references to the dictatorship, preferring to emphasise the plight of young conscripts who were sent to the Malvinas. These either glorified the bravery shown by conscripts and/or the hopelessness of their situation, forced to fight in a war with a world superpower for which they were ill-prepared (although some veterans took issue with these discourses which represented them as 'victims', further illustrating the tensions inherent to remembering the war). ${ }^{99}$ Thus, the role of the dictatorship was sometimes implied, through references to the dire experiences of conscripts during the war, yet in ways which avoided explicit criticism (that these experiences were the result of mistreatment at the hands of superior officers, for example). Whether subsequent discussions about the historical context underpinning the war then took place in classrooms seemed to be a decision left to individual teaching staff. The local social and institutional context meant that

\footnotetext{
99 Lorenz, Las guerras por Malvinas; Guber, 'Bautismo de fuego'.
} 
in contrast to emerging state narratives of memory, the connections between the dictatorship and the Malvinas War were rarely substantially explored. This was despite the national holidays remembering the victims of state terror (24 $4^{\text {th }}$ of March) and the fallen in the Malvinas War ( $2^{\text {nd }}$ of April) being marked within just over a week of one another. ${ }^{100}$ These dates typically encompassed discrete activities within schools rather than any efforts to interrogate the dictatorship as the common denominator connecting the two.

One possible reason for this was the prominent role of veterans in schools around key dates associated with the Malvinas, who were more likely to talk about their experiences of the war rather than the broader political context in which it took place, as one might expect. They were perhaps wary of making such connections, given the difficulties Argentine society had in distinguishing between elements of the military in the immediate post-dictatorship era; for example, between the officers who had perpetrated or ordered human rights abuses against civilians in Argentina and conscripts of the Malvinas campaign, and young Argentine men who had been obligated to fight for the patria. ${ }^{101}$ Since then there has been gradual change and veterans of the war have received more recognition and empathy from the Argentine government and society in general, notwithstanding the continued grievances of many at what they consider to be inadequate state support. ${ }^{102}$

\footnotetext{
100 Interestingly, during a visit to a public school in Santa Fe in April 2015 an explicit link was made between these two national dates, as they were commemorated together during the same ceremony. Although anecdotal, it is suggestive of an approach which more closely resembles state narratives of memory in terms of linking the Malvinas War to the context of the dictatorship. For an additional reflection on how the dates might be remembered together see Lorenz, 'Se habla de Malvinas'.

${ }^{101}$ Natasha Niebieskikwiat, Lágrimas de hielo: torturas y violaciones a los derechos humanos en la guerra de Malvinas (Buenos Aires: Grupo Editorial Norma, 2012).

102 The gathering of veterans in many central plazas in cities throughout Argentina is testament to these grievances which centre on, for example, the issue of financial support through state pensions and (mental) health provision. In recent years debates about who should be eligible for the pension have sparked angry protests with some arguing the category 'ex-combatant' should include those who were on standby in the continent in 1982 but who did not see action in the south Atlantic.
} 
These developments in how the Malvinas War is remembered have seen veterans become increasingly visible in public life in Argentina and this has extended to their engagement with schools. The deep connections to the military evident in Río Gallegos have meant that they play an important role in how schools remember and commemorate the war:

'What differentiates Santa Cruz from other provinces doesn't have so much to do with the teaching, rather it has to do with the fact that the people are more exposed to how the war was here, where the people were, the soldiers, so it cuts across the lives of some families. Now, in that sense it can be more present and also the veterans have a very important job here. They go to schools, they put on events, commemorative acts and they now join in with the politics of the state, so now they have even more presence in the public agenda'. ${ }^{103}$

There was a sense that veterans also wanted to avoid desmalvinizar or collective amnesia of the Malvinas cause within Argentine society and talking to young people in schools was one way in which they could contribute to keeping these memories 'alive'. ${ }^{104}$ The cause in this sense can be variously defined and includes bringing attention to the veterans' continued fight for reparation from the state through adequate pensions and more widely Argentina's sovereignty claim over the Islands, which most veterans considered to be just and legitimate. They provide further evidence that the perspectives of teachers and the analysis of curricula alone are insufficient if one is to fully grasp how recent historical events are remembered in school settings. ${ }^{105}$

Education officials in Argentina's Ministry of Education welcomed the input of veterans, considering them as 'interlocutors' in how the Malvinas War was remembered in teaching

\footnotetext{
${ }^{103}$ Interview with a private secondary school history teacher, Río Gallegos, 7 March 2013.

${ }^{104}$ Lorenz, Las guerras por Malvinas; Scorer, 'From la guerra sucia'.

105 Vom Hau, 'Nationalism and War Commemoration'.
} 
materials and schools. ${ }^{106}$ The visits of veterans to schools were not seen as a challenge to national narratives of memory but it was made clear that the role of teaching young people about the war should not be delegated to them. This suggests that education officials recognised the pedagogical limitations of veterans' accounts as they were unlikely to contextualise the events surrounding the war itself. The ministry promoted dialogue with a range of different actors including veterans but maintained that responsibility for memory education rested with national and provincial ministries, as well as individual institutions and their teaching staff.

Teachers in Río Gallegos responded in different ways to veterans entering the classroom to talk about the Malvinas War. The majority were positive about such contributions and claimed that young people became more interested when veterans participated in classes, in similar ways to the involvement of local civilians detailed above. Very often young people's learning about the Malvinas War was not restricted to the school classroom as they visited the museum run by veterans, local commemorative monuments, as well as active military bases in the city. Memory narratives were constructed through a combination of adults (civilians and veterans of the war in Río Gallegos) entering schools to present their experiences and young people going out to various sites connected to the war. There was considerable porosity between these spaces that has not been sufficiently acknowledged in the existing literature on memory and commemoration. ${ }^{107}$ Most of this research has tended to look at sites (e.g. schools), actors (e.g. teachers) and the resources (e.g. textbooks) used

\footnotetext{
${ }^{106}$ Interview with an education official, Argentina's Ministry of Education, 20 March 2013.

${ }^{107}$ Atkinson, 'Kitsch Geographies'; Bellino, 'Whose Past'.
} 
therein in rather bounded ways, overlooking how they might be complemented/challenged by other spaces, actors and memory narratives. ${ }^{108}$

Equally important to consider here are the relationships between the different actors situated across these spaces (i.e. teaching staff and veterans in this case), as the opportunity to remember the Malvinas War through veterans entering the classroom was not received with the same enthusiasm by all teachers:

'Regarding the testimonies of veterans, firstly, I've never invited them to my classes or for the $2^{\text {nd }}$ of April and I consider it a very partial vision, very subjective and not very critical of the war. A veteran who suffered and saw his fellow soldiers killed cannot make one understand this war'. ${ }^{109}$

'The veterans came to the school because they were invited and they gave a talk....But like I told you, the school favoured the idea that there would be balance with respect to the sources. Not just to look at one side, rather for the students to look at various sides so they are able to make their own conclusions'. ${ }^{110}$

These private school history teachers had different views about how the testimonies of veterans were to be included in the classroom. The first made the decision not to invite them into her classes because she claimed that they would not provide a critical understanding of the war (i.e. its historical context in relation to the dictatorship and arguments about its justification). The second worked in a school that ensured their students were exposed to a range of different perspectives concerning the Malvinas War

\footnotetext{
108 Vom Hau, 'Nationalism and War Commemoration'; Ram, 'The Immemorial Iranian Nation?'; Escudé, 'Argentine Territorial Nationalism'.

109 Interview with a private school history teacher, Río Gallegos, 15 March 2013.

${ }^{110}$ Interview with a different private school history teacher, Río Gallegos, 7 March 2013.
} 
and the sovereignty question. Consequently, the testimonies of veterans were placed alongside other sources such as documentaries, newspapers, books and magazines from Argentina and the UK in order to identify the subjectivity inherent to different accounts of the war. As the second interviewee intimates, more broadly, teachers in private school settings were able to decide how (and indeed whether) veterans' accounts might be incorporated into their teaching. Once again, there was evidence here to suggest that ways of remembering the war (e.g. in terms of the teaching resources used and the actors invited to speak at schools) were different in public and private institutions. Teaching staff in private institutions explained how they did not necessarily subscribe to localised expectations and/or state narratives of memory in quite the same ways as their public counterparts (for some of the reasons discussed in the previous section). Thus, the institutional status of the school was significant alongside consideration of how individual teaching staff negotiated these narratives according to their political views, pedagogic approach and personal histories related to the Malvinas War. ${ }^{111}$

\section{Conclusion}

Writing on memory has become increasingly sensitive to spatial and temporal variations in the production, performance and reception of memory narratives. ${ }^{112}$ The research presented in this paper has drawn on this work and applied it more explicitly to themes of memory and commemoration in relation to the Malvinas War in Argentina, a subject which has received little research interest from memory scholars in Latin America, relative to

\footnotetext{
${ }^{111}$ Vom Hau, 'Unpacking the School'; Matthew C. Benwell, 'From the Banal to the Blatant: Expressions of Nationalism in Secondary Schools in Argentina and the Falkland Island', Geoforum, 52 (2014), pp. 51-60.

${ }^{112}$ See Bosco, 'Human Rights Politics'.
} 
domestic state terrorism. ${ }^{113}$ At the same time it has extended these debates by highlighting when and under what conditions collective memory narratives at the national scale might be altered and/or reinforced in localised settings. Drawing on the research of Conway and others, it suggests a framework for conceptualising the reception and (re)interpretation of memory narratives associated with the 1982 war; one which examines the social, political and institutional contexts in which memory work takes place and the actors involved, at both national and local scales. ${ }^{114}$ This approach offers an opportunity to more comprehensively understand the sensitivities and power struggles associated with remembrance and commemoration of traumatic events like the Malvinas War.

The Malvinas have become far more visible as a geopolitical priority and as part of state narratives of memory in Argentina in recent years. These narratives have: a) emphasised the historical longevity of Argentina's sovereignty claim, moving the focus away from the 1982 war and b) looked to contextualise the war alongside memories of the last military dictatorship. However, there are tensions between these national narratives and their localised reception. In Río Gallegos, there are specific histories and sensitivities which have seen memories of the 1982 war dominate (as opposed to other historical periods). These have tended to draw on local experiences of the war specifically, both from civilian and military perspectives, in ways which marginalise deeper interrogation of the prevailing socio-political conditions affecting Argentina at this historical moment. Although the military profile of the city of Río Gallegos has been an important focus here, the paper has suggested the ways in which other cities in Argentina might face similar conflicts over how the dictatorship and state terror are remembered alongside the Malvinas War. For example, Río

\footnotetext{
113 Francesca Lessa and Vincent Druliolle (eds.), The Memory of State Terrorism in the Southern Cone: Argentina, Chile and Uruguay (Basingstoke: Palgrave-MacMillan, 2011); Ros, The Post-Dictatorship Generation ${ }^{114}$ Conway, Commemoration and Bloody Sunday; Ghoshal, 'Transforming collective memory'.
} 
Gallegos is not alone in hosting a centre for Malvinas veterans and these actors play an important role in shaping memory in many other cities throughout Argentina. There are marked divisions, even among groups of veterans, about how the war should be remembered. This fact alone reaffirms the importance of contextualising narratives of memory at different scales and recognising how the presence (or absence) of actors such as war veterans, might serve to re-work or reproduce official narratives.

Finally, the paper has shown how questions related to national and local memory narratives can be productively analysed through educational settings. The majority of existing work on memory has tended to reductively analyse educational materials produced by the state, encouraging a rather uniform understanding of how the nation's classrooms might be remembering key national events. ${ }^{115}$ Through engaging educational officials, teachers and others involved in memory work in schools alongside educational resources produced at both national and local scales, the research presented here illustrates the varied ways memory can be interrogated in classrooms and more importantly the reasons underpinning contestation and/or reproduction of official memory narratives.

\footnotetext{
${ }^{115}$ Although see Bellino, 'Whose Past'; Faden, 'History Teachers Imagining'; Bhattacharya, 'Teaching History in Schools'; Vom Hau, 'Unpacking the School'.
} 